$\begin{gathered}\text { EPiC Series in Education Science } \\ \text { Volume 1, 2017, Pages 70-77 }\end{gathered}$
$\begin{gathered}\text { AUBEA 2017: Australasian Universities Build- } \\ \text { ing Education Association Conference 2017 }\end{gathered}$

\title{
Preparing Students for a Disruptive Construction Future
}

\author{
Mary Hardie ${ }^{1^{*}}$ \\ ${ }^{1}$ Western Sydney University, NSW, Australia. \\ m.hardiedwesternsydney.edu.au
}

\begin{abstract}
Many industries have felt the impact of disruptive change on their profitability and established practices. Examples of disruption have been documented in industries as diverse as transportation, photography, newspapers, retailing, recorded music and computer graphics. The construction industry has mostly avoided large-scale disruption because, in spite of the globalisation evident in mega projects, most construction is locally-based and delivered within a specific national context and regulatory system. This may be about to change. The forces of digitisation, industrialisation and globalisation are combining to generate the potential for disruptive enterprises which will grab market share and shake up existing business models. As academics striving to prepare students to be employment-ready, we need to open their eyes to the potential of the new economy to support new business models that are quite different from traditional construction companies. Students will need to be entrepreneurial in seeking out opportunities and identifying market niches. In two new and developing units/subjects at an Australian university these issues are being raised. Students are challenged to identify markets and market strategies enabled by social enterprises, collaborative systems, the 'Internet of Things' and even 'Brutal Innovation'. Using student feedback and reflective practice, the lessons from the first two offerings of the new units are identified and teased out. In general, students respond well to the challenge of strategic thinking which relates to their future careers. While predicting the future is always fraught with difficulty, not attempting to do so could leave us vulnerable to disruptive change.
\end{abstract}

\section{Introduction}

Many students studying construction management today are true natives of this century. They have no memory of the twentieth century and are often very much transitioning to what is now called 
the $4^{\text {th }}$ industrial revolution (Schlick 2012). As explained by Bloem et al (2014), the First Industrial Revolution commenced with the harnessing of water and steam power at the end of the $18^{\text {th }}$ century. The second stage was the introduction of mass production and the conveyor belt at the beginning of the twentieth century. The third phase is the digital automation of production utilising IT from the 1970s onwards. The fourth Industrial revolution is said to be happening now. This is predicted to involve increasing collaboration between humans and machines to the point of fusing the physical, digital and biological realms (Dombrowski and Wagner 2014). The world where the next generation of construction leaders will play out their future careers may be strongly influenced by digital complexity, globalisation, product industrialisation and market volatility. It will almost certainly be significantly different from that of past generations. Given the potential for significant disruption in the industry, it is important that educators foster discussion into the paths that the industry may take in the future. Many of our digitally literate students are already looking at the potential opportunities opening up for flexible, creative and innovative people to build themselves new enterprises and new ways of operating a construction business. We may already have some global game-changers amongst us. As educators, it is important that we are flexible in our response to external forces promoting change. New structures, content and assessments will be needed to make sense of the changes as they occur. The aim of this paper is to report on attempts to introduce the concepts of rapid and disruptive industry change to current students, so that they can seek out new opportunities in their future careers. They may even need to cope with an eras of brutal innovation where change processes wipe out past practices completely.

\section{Literature Review}

\subsection{Digitisation}

The introduction of computer technology in its many forms to the construction industry can be described as the process of digitisation. The gradual penetration of the digital world into the processes of construction has been studied by several authors. Shibeika and Harty (2015) found that the digital infrastructure to deliver innovation is incomplete and tends to result in tension between standardisation and customisation. Organisational change within a firm was found to strongly effect the diffusion of digital technology. Similarly, Osterreich and Teuteberg (2016) found that the uptake of digital technologies known as Industry 4.0 is patchy in the construction industry in the UK. However, they did find best practice examples that could demonstrate the benefits of digitisation to slow adopters. On the positive side, Ingram (2016) reported that construction businesses are being transformed by social media, mobile computing, cloud computing, data analytics and the Internet of Things (IoT). These drivers of change increase the pressure to perform for construction companies, but they also provide opportunities to create new kinds of construction enterprise. Case studies such as Merschbrock and Munkvold (2015) demonstrate the effective deployment of digital tools in a complex hospital building project. Ding et al (2014) found that the use of BIM technology enables dynamic and virtual analysis of scheduling, costing, stability, sustainability, maintenance, evacuation simulation and safety. While this possibility is there, it is yet to reach through to many construction operations. There is, however, some evidence that the digitisation of construction processes can improve the value delivery to clients (Sanchez et al 2016). Despite distinct unevenness in the uptake of digital technology in construction projects, it is now clear that the potential efficiencies are very significant. Students seeking to build a career in construction management in the coming decades will need to be tech-savvy and willing to adopt new methodologies and means of operating if they are to remain competitive. 


\subsection{Industrialisation}

Off-site manufacturing of elements of building fabric and contents can be described as industrialisation of the industry. The growing trend towards this industrialisation has been observed by many authors with varying conclusions and recommendations. Jonsson and Rudberg (2014) developed a classification system to describe the degree to which industrialisation has been adopted on different construction projects. They found a classic dichotomy between the productivity benefits of industrialisation and the flexibility of outcomes available to customers. Ramaji and Memari (2016) studied modular construction models and found that information management systems already deployed in manufacturing were unsuitable for project-based modular construction incorporating modular factory-produced components. The authors propose a new Product Architecture Model (PAM) to incorporate the benefits of modular building into BIM and enable accurate life cycle assessment of multi-storey modular buildings. Santiago et al (2013) designed a factory layout that was dimensioned to suit a standard shipping container. They found significant cost and time benefits in comparison to onsite construction. The cost barriers to offsite construction were specifically examined by Pan and Sidwell (2011). The authors found that the increasing trend to offsite construction needed to be supported with long-term commitment so that individual constructors could gain experience with the delivery of such projects. Once a learning curve was established, cost benefits were seen to flow, but this did not happen automatically. Wong et al (2017) examined the readiness of some Australian construction companies to embrace prefabrication. While signalling some potential issues, they noted that many constructors saw the wisdom of the move to greater prefabrication and the benefits that can be claimed if organisational changes are made.

The various forms of prefabricated, modular, panelised and volumetric construction as well as the 'componentisation' of building elements such as bathroom pods have become increasingly common in recent years. Significant investment in these areas is happening in several parts of the world. Consequently, it is important that construction students are aware of the move to reducing the onsite effort in construction projects and replacing this without offsite effort. This will impact the nature and extent of employment in the future construction industry. Students who are alert to the possibilities of these changes are more likely to be able to identify future opportunities.

\subsection{Globalisation}

The third significant trend identified from the literature on construction industry futures is globalisation. Globalisation has been described as "the inexorable integration of markets, nation-states and technologies to a degree never witnessed before in a way that is enabling individuals, corporations and nation states to reach around the world faster, deeper and cheaper than ever before" (Friedman 1999 p.9). Recent times have seen some political setbacks for this "inexorable" process which may not be as inevitable as the author perceived it. It is nevertheless true, that globalising forces persist in mercantile economies and are likely to continue to do so. While the construction industry has been largely insulated from the globalisation forces that have changed many other industries, this is not likely to remain the case in the future. Ngowi et al (2006) described the globalisation of infrastructure developments and their financing. The impact of this trend has already driven procurement and participation changes in many parts of the developing world (Badu et al 2012). The construction of 'mega-projects' has seen a dramatic rise in multi-national construction effort in many parts of the world. Mok et al (2015) undertook a systematic review of construction mega projects and found that such projects require a careful stakeholder management process if they are to succeed in a globalised world. Bi-lateral and multi-lateral Free Trade Agreements accelerate this process. Quality control in a globalised construction market has been demonstrated to be problematic in a number of recent cases of sub-standard building material substitutions, notably in the 
Docklands Lacrosse Tower fire in Melbourne in 2015. There are potential new careers being developed in the international assurance and certifying of new global procurement systems.

\subsection{Disruption}

The convergence of the three previously identified trends in the construction industry has the potential to create disruption in the manner experienced by many other industries. Since the early 1990s when he completed his PhD, Clayton Christensen has written extensively about the concept of 'market disruption' as a pathway for innovation delivery (Christensen 1992; Christensen 2006; Christensen et al. 2000; Christensen \& Tedlow 2000; Christensen et al. 2002). He defined a disruptive innovation as one that creates a new market and value network and thereby disrupts and displaces an established market including its leading firms and alliances. Disruption has been documented in industries as diverse as health care (Christensen et al 2000), transportation (Cho and Parsons 2015), photography (Čiutienè and Thattakath 2014), newspapers (Karimi and Walter 2015), retailing (Christensen and Tedlow 2000), recorded music (Moreau 2013) and computer graphics (Pimentel 2015). Potential disruptive innovations identified by Jang (2013) include wearable computers, 3D printing, context awareness technology, driverless cars, ultra-light materials, gene therapy, and post batteries. At least some of these may impact on the construction industry. Rather than being overtaken by these changes, construction students need to identify the opportunities and make themselves part of the change delivery process rather than its potential victims. The identification of 'game-changing' trends in the construction industry will enable the students of today to start looking for these opportunities for a future rapidly moving global context. The process is presented graphically in Figure 1 below.

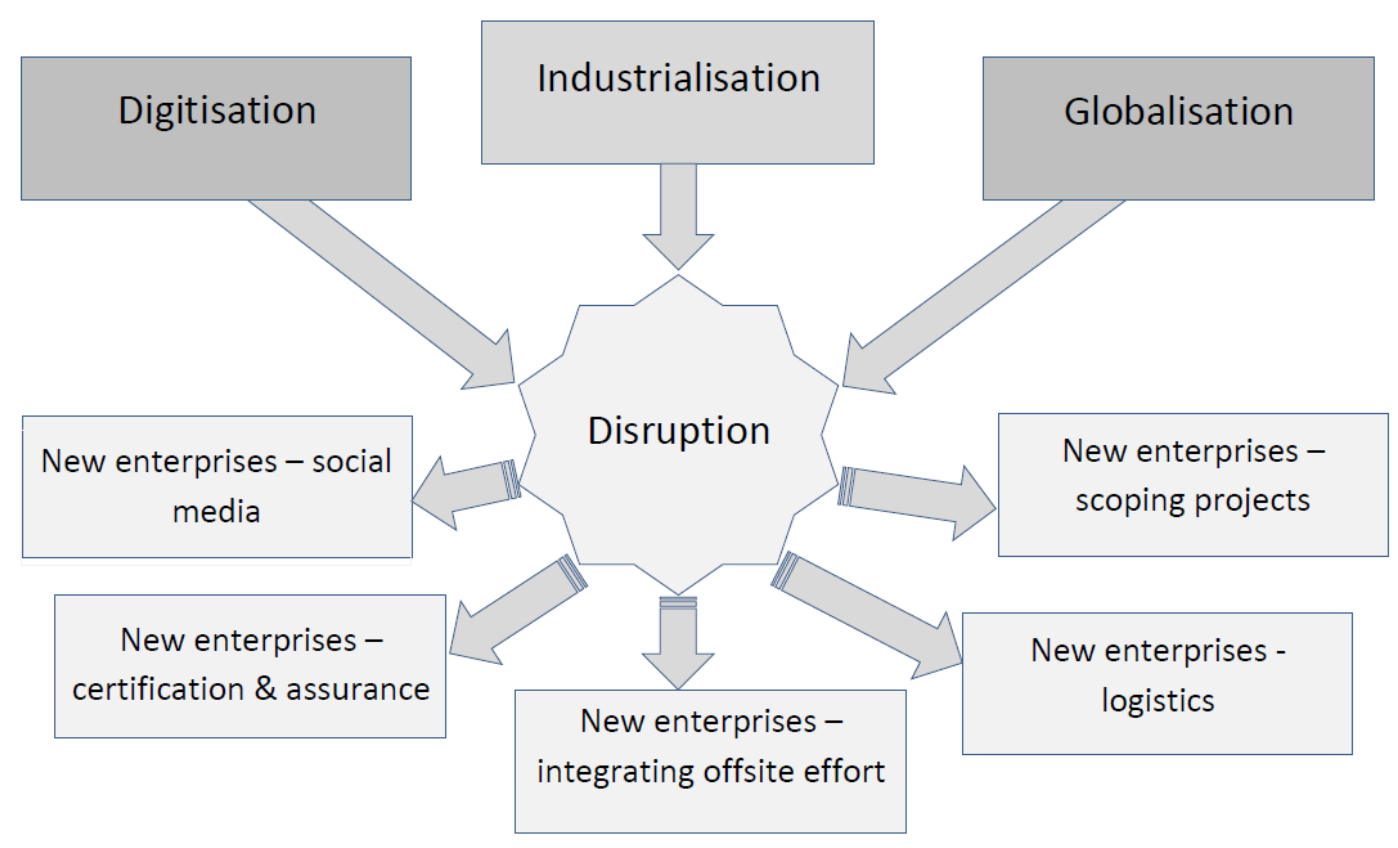

Error! Reference source not found. Disruption Process

The new enterprise examples presented in Figure 1 arose as a result of discussion between the students and staff members as described below. 


\section{Methodology}

For an educator reflective practice is about examining one's actions so that one can engage in a process of continuous learning. Paying critical attention to the events and values presented in the course of teaching delivery, while being aware of the educational theories which underpin that delivery, is a useful methodological practice. It is qualitative in nature and its rigour as a research methodology is dependent on continuous and systematic monitoring of the impact of the teaching delivery. Student engagement is one measure of effectiveness. Formal and informal student feedback must be collected and should be addressed without prejudice with regard to whether or not it confirms the educational intention. The literature of teacher education is replete with discussions of reflective practice but so is the literature of professional development (Biggs 2001; Bolton 2010; Ryan 2013). The concept of work readiness as defined by Cabellero and Walker (2010) is also relevant to this discussion, but this research examines the future of work in the industry and speculates that it may be very different from the past.

\begin{tabular}{ll}
\hline On successful completion of this unit, students should be able to: \\
\hline 1 & $\begin{array}{l}\text { Analyse the opportunities presented by the changing global environment in construction } \\
\text { Compare and contrast the trajectories of attempts at innovation in the construction } \\
\text { industry }\end{array}$ \\
3 & $\begin{array}{l}\text { Predict major trends in construction modernisation } \\
\text { Hypothesise on the factors that contribute to successful modern construction enterprises }\end{array}$ \\
5 & $\begin{array}{l}\text { Make an original case for the adoption of changes to the way construction businesses } \\
\text { are structured }\end{array}$ \\
6 & Re-imagine construction enterprise models for the Indo-Pacific region \\
\hline
\end{tabular}

Table 1: Learning outcomes for Modern Construction Enterprises

\begin{tabular}{ll}
\hline \multicolumn{4}{c}{ On successful completion of this unit, students should be able to: } \\
\hline 1 & $\begin{array}{l}\text { Analyse the available indices that are used to measure construction productivity } \\
\text { Construct a case for improving project efficiency by means of industrialising } \\
\text { construction projects }\end{array}$ \\
3 & $\begin{array}{l}\text { Examine ways to address quality assurance in a globalised construction market } \\
\text { Review the impact of the need for buildings to be adaptable over their useful lifetime } \\
\text { Theorise about the way to ensure that end users receive economic, environmental and } \\
\text { social value from their buildings }\end{array}$ \\
\hline Table 22: & Learning outcomes for Modern Construction Projects
\end{tabular}

Table 22: Learning outcomes for Modern Construction Projects

This paper reports on the first delivery of two newly developed units in the recent 2017 Summer and Spring semesters at an Australian university. The units are called Modern Construction Enterprises and Modern Construction Projects. They are currently offered as electives to later year Bachelor of Construction Management students. The enrolment in the units was 25 and 35 respectively. This was particularly pleasing as no advertising or promotion of the new units to students was done at this time. However, it must be acknowledged that this leads to a bias towards the more engaged and active students undertaking the units. The units are differentiated by their emphasis on adaptation of the whole business in the first instance versus emphasis on procurement and project delivery in the second case. This differentiation was essential for the three stage unit approval system at the university which requires academics to be able to explain the learning intent to academics from other disciplines. The approved Learning Outcomes for the units are shown in Tables 1 and 2 above. As part of the reflective practice, both the academic and the industry advisor attended all the face to face sessions in the first delivery of the units. They took turns teaching and taking notes on the 
process. These peer observation notes will be used to develop and inform future offerings of the units. Of course, the success or otherwise of the units is judged by how well the students manage to meet the prescribed learning outcomes. This will become more apparent when they have been offered multiple times.

\section{Results and Discussion}

This paper reports on a work in progress. The new units have only been delivered once at the time of writing. A great deal of preparation was done to ensure that the material presented was up to date and relevant to the Australian industry context. Guidance was given in these matters from the codeliverer of the units who is an experienced industry practitioner with an interest in fostering a new approach to organising and measuring productivity in the construction industry. For the Summer unit, only two students failed and this was due to their not submitting all the assessments. On contacting both students, it was revealed that 'pressure of work' was nominated as the reason for failure to complete the unit. The marking spread was skewed towards the high grades (3 High Distinctions, 6 Distinctions, 9 Credits, 5 Passes and 2 Fail Non Submits). It was not possible to use the official Student Feedback on Unit data for this unit because the numbers responding to the survey were too small. Despite their reluctance to go through the official channel, students did provide informal feedback through other means. Two students posted on LinkedIn ${ }^{\mathrm{TM}}$ demonstrating their unprompted enthusiasm for the just completed unit:

"Just completed my last lecture of the new "Modern Construction Enterprises" unit offered by xxxx University. A great unit with stimulating insights that left me excited about the future of the Construction Industry. Well done xxxx....” Student MS

"I would love to the take the time to appreciate one of my universities senior lecturers who has dedicated her time and effort into establishing and developing a new unit called 'Modern Construction Enterprises' in which has allowed myself to explore and develop a greater understanding of the construction industry today and how innovative technologies are changing the way we build but also realising the downfalls that aren't quite working in the industry. I wanted to thank you for giving up your time to fulfil our minds as a student, hoping to take what I've learnt and to establish a career."

Student BK

While these testimonials are pleasing and they received many likes from past students, they were reinforced by several informal comments and by the quality of the work that the students were able to deliver. The most important general criticism was that students wanted to see how the issues of sustainability and livability of construction output could be addressed alongside the change management described in the unit. This topic will be addressed in the next iteration of the unit. The peer observation feedback indicated a strong need to get students actively engaged in the material delivery. This will be the main target for the second offering. Development of new learning material is demanding of an academic's time and new units that look at the recent developments and future trends will need to be comprehensibly updated for each delivery. They cannot be static. Nevertheless, the first attempt was a positive experience and will be persisted with. Formal feedback on the second unit was not available at the time of writing. It will be available before the conference and could be included at that time. 


\section{Conclusions and Limitations}

It can be difficult to find the time to work on new course material in high demand study areas like construction management. The results of this experience were positive and invigorating albeit very preliminary in terms of verified research. Future offerings of the unit will be moving towards more active student participation in order to ensure that the units remain up to date and relevant. It is the author's hope and intention to continue with this work and report back on it in future AUBEA conferences in order to receive feedback from colleagues and to hear what reflective practices they are undertaking.

\section{References}

Badu, E, Edwards, D, Owusu-Manu, D \& Brown, D 2012, 'Barriers to the implementation of innovative financing (IF) of infrastructure', Journal of Financial Management of Property and Construction, vol. 17, no. 3, pp. 253-73.

Biggs, J 2001, 'The reflective institution: Assuring and enhancing the quality of teaching and learning', Higher Education, vol. 41, no. 3, pp. 221-38.

Bloem, J, Doorn, M, Duivestein, S, Excoffier, D, Maas, R \& Ommeren, E 2014, The Fourth Industrial Revolution, VINT.

Bolton, G 2010 3rd edition, Reflective practice: writing and professional development, Sage Publications, Los Angeles.

Caballero, C \& Walker, A 2010, Work readiness in graduate recruitment and selection: A review of current assessment methods. Journal of Teaching and Learning for Graduate Employability, 1(1), 13-25.

Cho, A \& Parsons, J 2015, 'Transportation Industry Faces Digital 'Disruptions", ENR: Engineering News-Record, vol. 274, no. 2, pp. 1-.

Christensen, CM 1992, 'The Innovator's Challenge: Understanding the Influence of Market Environment on Processes of Technology Development in the Rigid Disk Drive Industry', DBA thesis, Harvard University, Cambridge, MA.

Christensen, CM 2006, 'The Ongoing Process of Building a Theory of Disruption', Journal of Product Innovation Management, vol. 23, no. 1, pp. 39-55.

Christensen, CM, Bohmer, R \& Kenagy, J 2000, 'Will Disruptive Innovations Cure Health Care? ', Harvard Business Review, vol. 78, no. 5, pp. 102-12.

Christensen, CM \& Tedlow, RS 2000, 'Patterns of disruption in retailing', Harvard Business Review, vol. 78, pp. 42-5.

Christensen, CM, Verlinden, M \& Westerman, G 2002, 'Disruption, disintegration and the dissipation of differentiability', Industrial \& Corporate Change, vol. 11, no. 5, pp. 955-93.

Čiutienè, R \& Thattakath, EW 2014, 'Influence of Dynamic Capabilities in Creating Disruptive Innovation', Economics \& Business, vol. 26, pp. 15-21.

Ding, L, Zhou, Y \& Akinci, B 2014, 'Building Information Modeling (BIM) application framework: The process of expanding from 3D to computable nD', Automation in Construction, vol. 46, pp. 82-93.

Dombrowski, U \& Wagner, T 2014, 'Mental Strain as Field of Action in the 4th Industrial Revolution', Procedia CIRP, vol. 17, pp. 100-5.

Friedman, T 1999, The Lexus and the Olive Tree, Anchor Books, New York.

Jang, S-W 2013, 'Seven Disruptive Innovations for Future Industries', SERI Quarterly, vol. 6, no. 3 , pp. $94-8$. 
Jonsson, H \& Rudberg, M 2014, 'Classification of production systems for industrialized building: a production strategy perspective', Construction Management and Economics, vol. 32, no. 12, pp. 53-69.

Karimi, J \& Walter, Z 2015, 'The Role of Dynamic Capabilities in Responding to Digital Disruption: A Factor-Based Study of the Newspaper Industry', Journal of Management Information Systems, vol. 32, no. 1, pp. 39-81.

Merschbrock, CM, BE 2015, 'Computers in Industry', Effective digital collaboration in the construction industry - A case study of BIM deployment in a hospital construction project, vol. 73, pp. 1-7.

Mok, KY, Shen, GQ \& Yang, J 2015, 'Stakeholder management studies in mega construction projects: A review and future directions', International Journal of Project Management, vol. 33, no. 2, pp. 446-57.

Moreau, F 2013, 'The Disruptive Nature of Digitization: The Case of the Recorded Music Industry', International Journal of Arts Management, vol. 15, no. 2, pp. 18-31.

Ngowi, AB, Pienaar, E, Akindele, O \& Iwisi, DS 2006, 'Globalisation of the construction industry: A review of infrastructure financing', Journal of Financial Management of Property and Construction, vol. 11, no. 1, pp. 45-58.

Oesterreich, TD \& Teuteberg, F 2016, 'Understanding the implications of digitisation and automation in the context of Industry 4.0: A triangulation approach and elements of a research agenda for the construction industry', Computers in Industry, vol. 83, pp. 121-39.

Pan, W \& Sidwell, R 2011, 'Demystifying the cost barriers to offsite construction in the UK', Construction Management and Economics, vol. 29, no. 11, pp. 1081-99.

Pimentel, K 2010, 'The Rendering Revolution: A Desired Disruption', Computer Graphics World, vol. 33, no. 2, pp. 6-7.

Ramaji, IJ \& Memari, AM 2016, 'Product Architecture Model for Multistory Modular Buildings', Journal of Construction Engineering and Management, vol. 142, no. 10.

Ryan, M 2013, 'The pedagogical balancing act: teaching reflection in higher education', Teaching in Higher Education, vol. 18, no. 2, pp. 144-55.

Sanchez, A, Hampson, K \& Vaux, S 2016, Delivering Value with BIM, Taylor and Francis, London.

Santiago, M, Alberto, J, Juan Gonzalez, V \& Carlos, B 2013, 'Flexible field factory for construction industry', Assembly Automation, vol. 33, no. 2, pp. 175-83.

Schlick, J 2012, 'Cyber-physical systems in factory automation - Towards the 4th industrial revolution', in 2012 9th IEEE International Workshop on Factory Communication Systems, pp. 55-.

Shibeika, A \& Harty, C 2015, 'Diffusion of digital innovation in construction: a case study of a UK engineering firm', Construction Management \& Economics, vol. 33, no. 5-6, pp. 453-66.

Wong, PSP, Zwar, C \& Gharaie, E 2017, 'Examining the Drivers and States of Organizational Change for Greater Use of Prefabrication in Construction Projects', Journal of Construction Engineering \& Management, vol. 143, no. 7. 